\title{
A Systematic Review of Research Exploring Stakeholder Views on the Kindergarten-school Transition
}

\author{
Anita Fleisz-Gyurcsik (Corresponding author) \\ Doctoral School of Education, University of Szeged, Szeged, Hungary \\ H-6722 Szeged, Petőfi Sgt. 30-34 \\ E-mail: gyurcsik.anita@edu.u-szeged.hu
}

Received: July 13, 2021

Accepted: August 30, $2021 \quad$ Published: August 30, 2021

doi:10.5296/jse.v11i3.18893

URL: https://doi.org/10.5296/jse.v11i3.18893

\begin{abstract}
A smooth kindergarten-school transition is till problematic, even though it has been receiving attention from researchers as well as education professionals (e.g. Heckman, 2011). It is clear to everyone that children, kindergarten teachers, primary school teachers, and parents are all greatly affected by the kindergarten-school transition (e.g. Correia \& Marques-Pinto, 2016). Therefore, the goal of my study is the systematic review of research exploring the kindergarten-school transition related views and opinions of the stakeholders. A search was conducted for English language studies that were published in peer reviewed journals between 1 January 2016 and 1 September 2020, in the ERIC, Scopus and the Web of Science databases. The expressions ,kindergarten school transition”; „transition into primary school”; „transition to school”; „starting school”; „beliefs concerning school transition” were used as search terms. A total of 646 publications were identified, of which 21 complied with the inclusion criteria. Those papers were included that present such empirical work that explore the views and opinions of stakeholders regarding the kindergarten-school transition of normally developing children. The present review considers six aspects: (1) the country where data were collected; (2) the phase of transition when data were collected; (3) the issue of transition studied; (4) participants; (5) data collection methods; (6) main results. The review showed that numerous questions regarding the kindergarten-school transition are researched worldwide. My study can serve a basis for understanding the problems of starting school in different countries, as well as to formulate further research questions, and to design further research.
\end{abstract}

Keywords: kindergarten school transition; transition into primary school; starting primary school; stakeholders' views, systematic review 


\section{Introduction}

One of the most critical periods in early childhood is the kindergarten-school transition (e.g. Margetts, 2004). Various research articles (e.g. Pianta \& Hamre, 2009) have shed light on the fact that experiences in kindergarten-school transition determine later school success. As a result of this, in recent years an increasing researcher attention has been devoted to the exploration of early childhood development and its long term effects. The conclusions of various longitudinal studies (e.g. Heckman, 2011) drew attention to the fact that investments in this period lead to financial return.

It is clear to everyone that beside the children, kindergarten teachers, primary school teachers and parents are also greatly affected by the kindergarten-school transition. On top of this, it is well known that by learning about the kindergarten-school transition related views and opinions of the stakeholders (the actors affected by the kindergarten-school transition, e.g. educators, parents) the kindergarten-school transition can be facilitated, made easier (e.g. Correia \& Marques-Pinto, 2016). Therefore, the goal of my study is the systemic review of research exploring the kindergarten-school transition related views and opinions of the stakeholders. My review shows which question of the kindergarten-school transition the researchers from various countries are interested in, as well as in what circles and by what methods they are seeking answers. Consequently, my results may serve as the basis for the detailed knowledge of the papers included in the review and performing further research.

Prior to the systematic review of research, it is important for me to remind everyone of the basic concepts of the subject, thus in the theoretical review I summarize the main definitions of (i) early childhood; the (ii) kindergarten-school transition and (iii) school readiness. Then, I present the selection process of the research exploring the subject of the kindergarten-school transition as well as the criteria of analysis. Subsequently, I review the research pieces included in the analysis progressing along the lines of the analysis criteria.

\section{Theoretical Framework}

\subsection{Review of basic concepts}

Early childhood is the period between birth and age 8, during which the already established functions, forms of behavior are consolidated and further develop. A great extent of physical, cognitive, social-emotional and language development is characteristic of this period (Alexander et al., 1988).

Various transitions happen in early childhood, which represent a switch from one education level to another, being placed from one environment into another (Fabian, 2007). One of the most critical periods in early childhood is the kindergarten-school transition (e.g. Margetts, 2004), which as a result of divergent school starting regulations in various countries encompasses the period between age 5 and age 7-8 (OECD, 2014). Starting school involves numerous difficulties, for example it requires the child to adapt to the new group, new roles, new teacher, new expectations (Bronfenbrenner, 1979; Margetts, 2004; Dockett \& Perry, 2013). How well children adapt to these, and what positive experiences they gain in the initial 
period of school, determines their subsequent school success (e.g. Alexander et al., 1988; Ahtola et al., 2015).

Britto's study (2012) emphasizes that the kindergarten-school transition is the result of three processes: (a) the children enter a new learning environment and adapt to it; (b) the families learn to cooperate with formal education; and (c) the schools take steps to introduce children to school life.

A key issue of the kindergarten-school transition is school readiness (Britto, 2012). Meisels (1999 quoted, Dockett \& Perry, 2002) identified four types of theoretical approach to the development of school readiness. These include that school readiness: (a) is a result of biological maturity - meaning that children progress through a series of development phases to become school ready; this process cannot be accelerated; (b) is a result of the child's knowledge and behavior - this approach considers school readiness as an endpoint: the child is either ready to start school or not; missing skills and knowledge can be taught; (c) is a result of the community, its values and expectations - thus the meaning of school readiness is different in different communities; the criteria of school readiness is determined together by the family, the school and society; (d) is a result of interaction - school readiness is an interaction between the child's previous knowledge and skills, genetic characteristics, maturity level as well as environmental and cultural experiences.

School readiness is a complex concept, we can read various definitions of it in literature, at the same time different studies agree that successful school start is determined by several areas closely connected to each other. According to Kagan, Moore \& Bredekamp (1995) successful school start is determined by 5 areas: (a) physical well-being and motor development; (b) social and emotional development; (c) approaches to learn; (d) language development; (e) cognition and general knowledge. According to Wesley \& Buysse (2003) successful school start is determined by 3 areas: (a) good physical and mental health; (b) effective communication skills; (c) an approach to learning characterized as enthusiastic and curious. Hair, Halle \& Humen (2006) also consider 3 areas significant from the aspect of school start: (a) cognitive development; (b) language development; (c) socioemotional development. Commodari (2013) considers four areas outstandingly important: (a) motor skills; (b) social skills; (c) a solid base of language and cognitive skills; (d) the ability to handle frustration and stress.

The main conclusion of the theoretical review is that the kindergarten-school transition is a critical phase of early childhood, since the kindergarten-school transition involves numerous difficulties for the child, the families and the schools. The central issues of the kindergarten-school transition are if the children are adequately ready for school. Successful school start is determined by several areas closely connected to each other. In the next part of my study I present the selection process of international research exploring the issue of kindergarten-school transition and the analysis criteria. 


\section{Methods}

\subsection{Research selection process and analysis criteria}

Systematic literature review were used. I searched for English language papers that were published in peer review system periodicals between 1 January 2016 and 1 September 2020, on the ERIC, Scopus and the Web of Science databases. I used the expressions ,kindergarten school transition”; „transition into primary school”; „transition to school”; ,starting school”; „beliefs concerning school transition" as key words. With these search settings I identified a total of 646 publications (Table 1).

Table 1. Number of hits per keyword from the 3 databases

\begin{tabular}{|c|c|c|c|c|c|}
\hline \multirow[b]{2}{*}{ Database } & \multicolumn{5}{|l|}{ Search word } \\
\hline & $\begin{array}{l}\text { kindergarten } \\
\text { school } \\
\text { transition }\end{array}$ & $\begin{array}{l}\text { transition } \\
\text { into primary } \\
\text { school }\end{array}$ & $\begin{array}{l}\text { transition } \\
\text { to school }\end{array}$ & $\begin{array}{l}\text { starting } \\
\text { school }\end{array}$ & $\begin{array}{l}\text { beliefs } \\
\text { concerning } \\
\text { school } \\
\text { transition }\end{array}$ \\
\hline ERIC & 2 & 2 & 224 & 53 & 1 \\
\hline Scopus & 1 & 3 & 104 & 78 & 1 \\
\hline Web of Science & 0 & 1 & 95 & 81 & 0 \\
\hline \multirow{2}{*}{ Sum } & 3 & 6 & 423 & 212 & 2 \\
\hline & \multicolumn{5}{|l|}{646} \\
\hline
\end{tabular}

After elimination duplicates 411 publications remained. Then by reading the abstracts I filtered out the papers that did not comply with the inclusion criteria. Those papers were included that present such empirical work, which explore the views and opinions of stakeholders regarding the kindergarten-school transition of normal development rate children. Therefore, I excluded: (a) theoretical type works (e.g. literature reviews, meta-analyses, systematic reviews, case studies); (b) studies exploring the school start of children suffering from inborn/acquired diseases; (c) works focusing on special learning need children; (d) works dealing with children with fitting in, learning and behavioral difficulties; (e) studies dealing with the kindergarten-school transition of prematurely born children; (f) publications focusing on transitions between lower and higher levels of education systems (e.g. transition between secondary school and higher education); (g) studies dealing with the transition from education into the world of employment; (h) works dealing with early childhood development (e.g. social, emotional, cognitive, language and motor development of children); (i) studies dealing with early childhood development programs (e.g. elaborating early childhood education programs and exploring their effectiveness); (j) publications presenting the development process of measurement devices; $(\mathrm{k})$ works dealing with other 


\section{Macrothink}

Journal of Studies in Education

ISSN 2162-6952 2021, Vol. 11, No. 3

themes (e.g. overweightness, obesity prevention in early childhood; the kindergarten-school transition of children with food allergies).

In the case of every excluded study, I noted which inclusion criterion it failed to comply with. Figure 1 describes in detail the selection process of studies exploring the kindergarten-school transition.

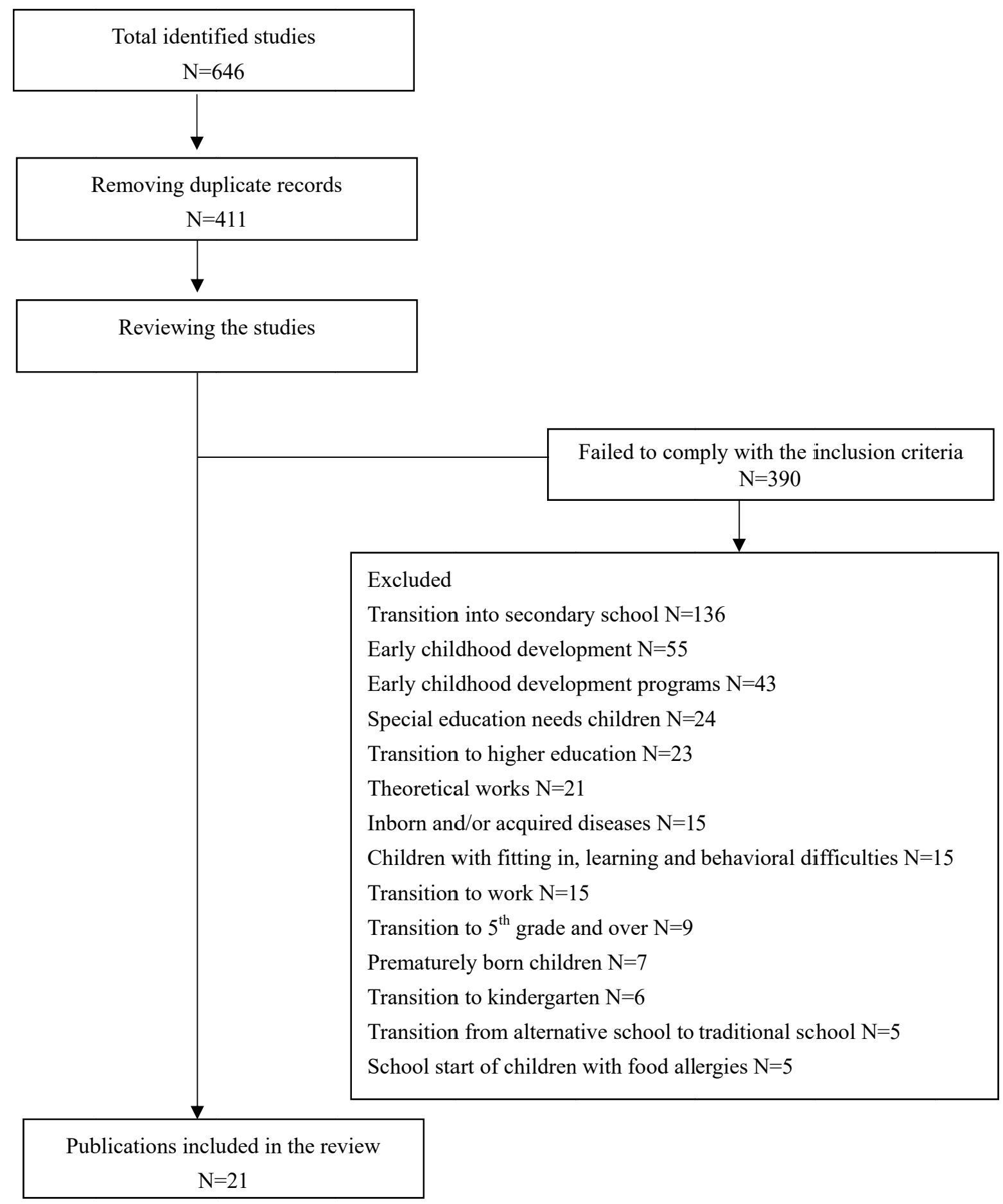

Figure 1. Flow chart of the selection process 
A total of 21 studies complied with the inclusion criteria. I reviewed these based on 6 aspects: (a) In which country was the data collected?; (b) In which phase of the kindergarten-school transition was the data collected?; (c) Which issue of the kindergarten-school transition do they aim to study?; (d) Among whom was the data collected?; (e) By what method was the data collected?; (f) What main result they gained?

In the next part of my paper I review the research pieces included in the analysis progressing along the lines of the analysis criteria.

\section{Results}

\subsection{Place of data collection}

The data collection location for the selected studies is given in Appendix 1. European and non-European countries appeared in roughly equal proportions in the studies. Most studies collected data in one country. I identified a study that aimed to compare the views of stakeholders living in six different countries. Five surveys were conducted in Australia. Three studies collected data in China, of which Wong (2016a; 2016b) reports the results of the same research in two different studies.

The majority of the studies do not indicate in which settlement the data collection took place. The research reviewed collected data in cities, suburbs and/or rural environments inhabited by families with low and/or high socio-economic status.

The education systems of different countries may have different structures, so whether pre-school education is compulsory or the number of years at which children start school may also differ. Table 2 illustrates where the studies included in the review were conducted and whether pre-school education is compulsory in the country, at what age children start first grade in primary school and report the percentage of first-graders by age. 
Table 2. Starting school age by countries and percentage of first graders by age according to OECD (2014) data - in alphabetical order

\begin{tabular}{|c|c|c|c|c|}
\hline \multirow[t]{2}{*}{ Country } & \multirow[t]{2}{*}{$\begin{array}{l}\text { Is kindergarten education } \\
\text { compulsory? }\end{array}$} & \multirow{2}{*}{$\begin{array}{l}\text { Starting } \\
\text { school age }\end{array}$} & \multicolumn{2}{|c|}{$\begin{array}{l}\text { Percentage of first } \\
\text { graders by age }\end{array}$} \\
\hline & & & 5 years old & 6 years old \\
\hline Australia & No & 5 & 86 & 100 \\
\hline Austria & Yes & 6 & 0 & 59 \\
\hline China** & No & 6 & n.d. & n.d. \\
\hline Croatia & Yes & 6 & 0 & 96 \\
\hline Estonia & No & 7 & 0 & 14 \\
\hline Finland & Yes & 7 & 0 & 1 \\
\hline Germany & No & 6 & 0 & 64 \\
\hline Greece & Yes & 6 & 0 & 96 \\
\hline Ireland & No & 5 & 99 & 100 \\
\hline Norway & No & 6 & 0 & 100 \\
\hline Portugal & No & 6 & 0 & 96 \\
\hline Slovenia & No & 6 & 9 & 93 \\
\hline $\begin{array}{l}\text { United Arab } \\
\text { Emirates * }\end{array}$ & No & 6 & n.d. & n.d. \\
\hline United Kingdom & No & 5 & 97 & 98 \\
\hline United States & No & 6 & 5 & 77 \\
\hline
\end{tabular}

Comment: n.d.=no data; *UNESCO (2010) ** Education Bureau (2016)

In most countries, pre-school education is not compulsory; I have identified four countries where children are required to attend pre-school education one year before starting school. The starting school age ranges from 5 to 7 years of age; in most cases, children start school after the age of six (OCED, 2014).

\subsection{Time of data collection}

I also analyzed at which stage of the kindergarten-school transition the data collection took place. Based on this, three groups emerged: (a) at the end of the senior group in kindergarten and in the few months after starting school; (b) at the end of kindergarten senior group; and (c) data collection in the period following start of school.

In the pre-school period, the research is mostly aimed at exploring the expectations and ideas of the stakeholders related to the school start, while in the period following start of school the researches reveal the experience already gained. The most common is the data collection a few months before the start of school and a few months after the start of school, in which the ideas 
and expectations of the stakeholders can be compared with the gained experience. Appendix 1 gives the time of data collection for each study.

Some of the researches included in the analysis (e.g., Tao et al., 2019; Wong, 2016a; 2016b) are part of larger, longitudinal data collection. It is well known that developmental relationships can be more accurately identified through follow-up studies. The longest-term research processes data collected from children aged six months to the end of first grade (e.g., Cook et al., 2017).

\subsection{Characterization of the studied sample}

A sample of the studies included in the analysis is detailed in Appendix 1. Most of the research explored collects data among children. After that, it is often common to examine the views of kindergarten teachers and primary school teachers together. An examination only of parents 'views appears to a lesser extent. Least characteristic are (a) the examination only of the opinions of kindergarten teachers; (b) the joint exploration of the views of kindergarten teachers, primary school teachers, and parents; (c) a joint examination of the views of primary school teachers and parents; and (d) getting to know the views of parents and their children together.

In the case of parents, mothers were the most involved in the research, which most authors see as a limitation of the research. Several studies (e.g., Jeynes, 2015) highlight the key role of fathers in children's development, so data collection may be worthwhile among them as well.

Regarding the sample size of the studies included in the analysis, it can be seen that the arrangement of the research varies from the smaller number of items (e.g. Correia \& Marques-Pinto, 2016) to the large sample number (e.g. Besi \& Sakellariou, 2019). Smaller and larger sample surveys occur in roughly equal proportions.

\subsection{Overview of the methods used}

A review of the methods (Appendix 1) shows that in most studies, data were collected through oral interviewing. According to the number of respondents, individual interviews are the most common, however, some research also conducted focus group interviews. Formally, the most common is the semi-structured interview; only a few studies conducted structured interviews. In one study (Miller, 2016), the method of a photo interview appeared - that is, the families involved in the study took photos for a week of activities they thought were related to their preparation for school, and then while reviewing the photos they told the interviewer what was happening regarding the given photo.

Two of the researches examining children's views and experiences (Wong, 2016a; 2016b; Kaplun, 2019) initiated a conversation with children based on children's drawings, that is, after the children had drawn their views on starting school, the person who carried out the study asked the children to tell what the drawing depicted, what was happening, and what the characters were doing in the drawing. It is common in the international literature (e.g. Careless \& Lam, 2014) to explore children's views in this way. 


\section{Il Macrothink}

\subsection{An overview of the topics explored}

The studies included in the review explore similar issues in the kindergarten-school transition. During the review of the research objectives, I identified six main research topics. These include, in order of frequency (a), exploring the skills needed to start school; (b) learning about ideas related to starting school; (c) cooperation, contact between stakeholders; (d) exploring parental involvement; (e) preparation for school; and (f) integration into school.

Most often, they aim to provide a detailed knowledge of one of the topics listed; it is less typical that several of the topics listed are explored (Appendix 1). I review the results of the studies included in the review by moving along the identified topics.

\subsection{Summary of the main results of the research}

\subsubsection{Exploring the skills needed to start school}

The studies included in the review have consistently concluded that the stakeholders interviewed believe that joint development of several areas is necessary to start school (e.g., Puccioni, 2018; Stein et al., 2019). Furthermore, Niklas et al. (2018) concluded from data collected in six different countries that the skills that stakeholders consider important for starting school differ from country to country, but at the same time the degree of independence, development of social skills and ability to maintain attention in each country was among the most important abilities.

Puccioni (2018) and Stein et al. (2019) concluded that the kindergarten teachers involved in its study believe that the proper development of basic reading skills (e.g. phonological awareness) is of high importance, and the ability of children to answer questions and talk fluently with teachers and peers. In addition, it is important that social skills (e.g. asking for help) are developed at the appropriate level and that children have a basic knowledge of themselves (e.g. they can say how old they are, they can say their addresses).

Kaplun et al. (2017) concluded that the majority of mothers identify school maturity with an appropriate level of development of cognitive abilities (e.g., the child knows numbers, letters). In addition, Kaplun et al. (2017) and Takriti (2020) drew attention to the fact that mothers consider it important for a child to start school that the child is interested in learning about school and new knowledge (e.g., expecting to be a schoolboy; interested in numbers, letters), and according to the opinion of the mothers, the appropriate development of social skills (e.g. openness; contact) is also important.

\subsubsection{Learning about ideas related to starting school}

Babić's (2017) results showed that children are well aware of the main differences between kindergarten and school - the kindergarten is mostly seen as where they can play with other children and they prepare for school in kindergarten, while in their view the school is the place, where they acquire new knowledge and receive a grade for their performance from the teacher. 


\section{I Macrothink}

After analyzing children's drawings, Kaplun (2019) concluded that children's perceptions of school differ greatly in the period before starting-and after starting school. The main difference in the children's drawings is the change in the basic activity - that is, before school started, the children depicted the school activities as playing on the playground; after starting school, the drawings already depicted a classroom with children sitting on benches, a blackboard, and a teacher. In addition, in the drawings made in the period before starting school, the children were usually alone or with their families. In contrast, in the drawings made in the period after starting school, children depicted themselves with their new friends instead of family.

Research findings (Eskela-Haapanen et al., 2016; Wong, 2016b) have highlighted that children have both positive and negative perceptions of starting school. Children of mothers worried about starting school and children of mothers who are less or not at all worried expressed similar views about the school, thus, mothers' concerns had no effect on children's views of school (Pass et al., 2019).

Eskela-Haapen et al. (2019) and Wong (2016b) found that in the period before starting school, girls' and boys' positive ideas about school are mostly related to their friendships - that is, it is key that they can meet old friends and/or they can have new friends at school. In addition to social relationships, other positive features of the period before starting school include informal school activities (e.g. free play in the school yard) and the acquisition of new knowledge (e.g. learning to read and write). According to Wong's (2016b) results, in the period after starting school, children prefer to go to school mostly because of their friendships, however, the acquisition of new knowledge was already considered less positive.

Eskela-Haapen et al. (2019) showed that before the start of school, the biggest fear of boys and girls about starting school was the orientation in the school building (e.g. whether they can find the classroom) and the adaptation to expectations and rules. In contrast, in Wong's (2016b) research, boys and girls were most afraid of developing negative peer relationships (e.g., aggression, conflict, exclusion) before starting school. Based on further results from Wong (2016b), this decreased by the end of the first grade, but there has been an increase in concerns about compliance with a reputable person (e.g., a teacher).

Wong's (2016a) results show that school playgrounds, classrooms, washrooms, corridors, and school buffets are the manifestations of aggressive behavior in schools. Before starting school, more girls reported that aggressive retention would appear at school, and after starting school, more girls reported school aggression than boys. Boys mostly talked about boy-boy school aggression, girls also experienced girl-girl and girl-boy aggression. Boys talked mostly about physical aggression, girls about verbal aggression. The boys and girls included in the study listed similar coping strategies: (i) the use of problem-solving strategies (e.g., asking the aggressor not to harm the victim; talking to the aggressor; ignoring the aggressor); (ii) asking for help from teachers or (iii) avoiding. In the period before starting school, most children mentioned the use of problem-solving strategies, while in the period after starting school, the focus was on asking teachers for help and avoiding. 


\section{Macrothink}

Booth et al. (2019) showed that children view school as (a) emotional; (b) cognitive; and (c) the one that requires behavioral regulation. Classroom activities related to learning to read, write, and count require a high degree of self-regulation.

\subsubsection{Cooperation and contact between stakeholders}

The studies reviewed (e.g., Besi \& Sakellariou, 2019; Stein et al., 2019) unanimously concluded that stakeholders believe that stakeholder collaboration is key in the transition from kindergarten to school, which should be based on mutual trust and respect. Nevertheless, research findings (e.g., Cook et al., 2017; Hopps-Wallis \& Perry, 2017; Nolan et al., 2019) have drawn attention to the fact that close, partnership-based cooperation and contact between kindergarten teachers, teachers, and parents is less common. The most common is the provision of one-way information to children (e.g. school visits, school open days) and / or parents (e.g. a presentation by an external professional on school maturity, development of basic skills) before starting school.

\subsubsection{Exploring parental involvement}

Studies included in the analysis (e.g., Kaplun et al., 2017; Rogers, 2018) concluded that parents 'beliefs about parental involvement in the period before starting school are inconsistent with their after starting school experience.

The research of Kaplun et al. (2017) has shown that parents see involvement in school life in the period before starting school by collaborating with the wider community (e.g., church, parents); they take an active, voluntary part in the life of the school and/or class and in the work of the school's parent bodies. At the same time, the after starting school data collection has already shown that the majority of parents see involvement in school in helping their child with homework and preparing for school work.

Tao et al. (2019) longitudinal study showed that the interviewed mothers expected to have time to read with their child before starting school, to tell a story to their child. However, after starting school, it was reported that this was largely pushed into the background. Before starting school, mothers said they would talk a lot with their child about their developing friendships. In contrast, after starting school, discussions are mostly about children's academic performance and school assignments. In line with their expectations, they found an increase in the quantity and quality of homework, which required them to supervise and / or help solve it, resulting in a reduction in the amount of time spent on the game.

\subsubsection{Preparation for school}

Kaplun et al. (2017) concluded that mothers described several ways to prepare for school. Most of these parents highlighted introducing the prospective teacher and the school, one possible way of which, they say, is to visit school. Prospective teachers will show these children the different rooms of the school and the children will be able to take part in school activities. According to the majority of parents, it is also typical for them to solve tasks aimed at developing writing and numeracy skills with their child at home. Half of the parents mentioned that the purchase of teaching aids and uniforms is also part of the preparation. 


\section{Mll Macrothink}

Journal of Studies in Education

ISSN 2162-6952

2021, Vol. 11, No. 3

In analyzing the preparation of families for school, Miller (2016) distinguished two groups of activities: (a) traditional activities; (b) non-traditional activities. Traditional activities included three activities: (a) solving worksheets; (b) learning to use computers and other technological tools; and (c) visits to school buildings. Non-traditional activities include two activities: (a) learning embedded in everyday activities (e.g., emphasizing the beginning letters of purchased products during shopping); and (b) learning, through family interactions (e.g., sharing, communication, conflict management).

\subsubsection{Integration into school}

Griebel et al. (2017) found that the vast majority of parents believe they have adapted well to having their child in school; only a negligible proportion of them stated that they had had a bad and/or very bad start in school. Their further findings showed that the majority of parents, after starting school, found that their child did not have any major difficulties in transitioning from kindergarten to school.

Correia \& Marques-Pinto (2016) found that parents raising a preschool child, parents raising a first-grade child, kindergarten teachers, and teachers similarly characterize a child who has integrated into the school world. These include (a) an interest in school assignments; (b) waiting to go to school; (c) does not want to go home from school; or (d) adheres to school rules.

The results of Correia \& Marques-Pinto (2016) highlighted that the stakeholders interviewed see differently what makes it difficult for children to integrate into school. According to parents raising a preschool child, the main problem is that the children are separated from the kindergarten teacher and their friends. According to the views of parents raising a first grade child, the main difficulty is that children have to understand the new daily routine and follow the new and strict rules. The majority of kindergarten teachers consider the fear of the unknown, while the teachers agree that the fear and anxiety about acquiring new knowledge is the main difficulty.

The results of Correia \& Marques-Pinto (2016) drew attention to the fact that the interviewed stakeholders see differently what most determines the smooth integration of children into school. The majority of parents raising a preschool child see that this is most determined by school and teacher-related characteristics (e.g., individual characteristics of the teacher; teaching methods used). The vast majority of parents raising a first-grader believe that this is mostly determined by family and school-related characteristics (e.g., quality and quantity of contact). Based on the views of kindergarten teachers, family-related characteristics play a decisive role in this (e.g., family views of school; family values), while teachers consider school-related and teacher-related characteristics to be the most dominant.

\section{Limitations}

One of the limitations of the study is that I used just three big databases. Another limitation is that I just five expressions were used as search terms. In the future, it may be appropriate to expand the range of databases and search terms. 


\section{Conclusion}

In the systematic review, I reviewed 21 studies aimed at gaining stakeholder views on the kindergarten-school transition. I presented the research in detail, broken down by the location of the studies, the time of data collection, the sample, the methods, the topics studied and the main results.

In terms of the location of the research, it is clear that the issue of kindergarten-school transition has been researched worldwide. By getting to know the views of stakeholders on the kindergarten-school transition, it is possible to facilitate the transition, and the widespread dissemination of practices to facilitate the transition.

Regarding the time of the data collection, it can be stated that the examinations were mostly carried out at the end of the senior kindergarten group and in the few months after starting school, so the expectations and views before starting school can be compared with the experience gained after starting school.

The studies included in the analysis put kindergarten teachers, teachers, children, and parents at the center of their study, among whom they collected data mostly through oral interviews. It is typical of research among children that they are asked to draw the school and talk to the children based on the completed drawings. Few analyzes have collected data using a questionnaire. The method of observation does not appear, although there may be factors that are difficult to identify with the interview and questionnaire method, but they can provide relevant information about the kindergarten-school transition. This could include observing the activities that kindergartens use to help develop the skills needed to start school, and the extent to which activities in schools are in line with the documents governing pre-school education, and the extent to which institutions take into account individual differences between children.

The studies included in the review explore similar topics in the kindergarten-school transition. These include, in order of frequency: (1) exploring the skills needed to start school; (2) learning about ideas related to starting school; (3) cooperation and contact between stakeholders; (4) exploring parental involvement; (5) preparation for school; and (6) integration into school.

The results show that the stakeholders believe that a successful start to school requires the appropriate development of several closely related areas. These results are consistent with the areas presented in the theoretical review. The interviewed children are well aware of the main differences between the kindergarten and the school institution. Both positive and negative factors were formulated about the school. Further results showed that close cooperation and liaison between stakeholders is less common. Parents see differently how they can get involved in school life in the period before starting -and after starting school.

Researchers around the world seem to be concerned about how stakeholders feel about certain issues in the kindergarten-school transition. This study provides an opportunity to learn more about research in detail, to formulate further research questions, and to design further research. 


\section{Discussion}

Based on my systematic overview, future research on the issues related to the transition from kindergarten to school should be approached using multiple methodologies. My study highlights the fact that the exploration of the opinion of stakeholders is best conducted through oral interviews. By examining the international literature, we can identify possible tools for measurement. The measurement tools employed in the works examined by the study could help researchers to employ a provenly useful questionnaire. We must not forget however that the structure of educational systems and school age regulations are different in each country, which means that measurement tools can only be adapted and tested if the educational system is similarly structured or if school age regulations are the same. The measurement tools in the examined studies can also serve as a sample for researchers and may aid them in developing other measurement tools. When designing measurement tools, we must ensure that stakeholders' views and opinions be examined in the same area, however it is also important for the measurement tools to contain specific questions

My study highlighted the fact that several issues regarding the kindergarten school transition have been examined through the eyes of stakeholders. However in the future it would be practical to explore the critical phases children go through according to stakeholders, how well they observe these developmental changes, how institutions support children's development, whether they pay attention to the individual differences between children that result from different developmental patterns, whether there are goals and tasks related to smooth school starting in pedagogical programs and local teaching programs, how effective the programs that aid transition are, what nursery and school practices they use to aid transition, and whether they organise further educational courses for teachers. Based on my systematic review, it would be practical to collect data from kindergarten teachers, primary school teachers, parents and even children to answer these questions. The possible sample may be expanded to include groups that could provide relevant information. This could include teachers and students at child development university courses as well as the operators of institutions. My study will also provide information on which stakeholders should be involved in the research and how.

In today's world everyone agrees that kindergarten school transition should be aided for children. If we get to know the stakeholders' views regarding the kindergarten school transition as well as the practices employed by institutions to aid the process, then we can provide information that could harmonise the two programs and may also help in developing new ones. Thus, examining the views of stakeholders may be useful for both teachers and curriculum developers, and research results may contribute to forming parental opinions through reasoned discourse.

\section{References}

References marked with an asterisk indicate studies included in the systematic review

Ahtola, A., Björn, P. M., Turunen, T., Poikonen, P. L., Kontoniemi, M., Lerkkanen, M. K., \& Nurmi, J. E. (2016). The concordance between teachers' and parents' perceptions of school 
transition practices: A solid base for the future. Scandinavian Journal of Educational Research, 60(2), 168-181. https://doi.org/10.1080/00313831.2014.996598

Alexander, K. L., Entwisle, D. R., Blyth, D. A., \& McAdoo, H. P. (1988). Achievement in the first 2 years of school: Patterns and processes. Monographs of the Society for Research in Child Development, 53, 1-157.

*Babić, N. (2017). Continuity and discontinuity in education: example of transition from preschool to school. Early Child Development and Care, 187(10), 1596-1609. https://doi.org/10.1080/03004430.2017.1301935

*Besi, M., \& Sakhttp://dx.doi.orgellariou, M. (2019). Teachers' Views on the Participation of Parents in the Transition of their Children from Kindergarten to Primary School. Behavioral Sciences, 9(12), 124.http://dx.doi.org/10.3390/bs9120124

*Booth, A., O'Farrelly, C., Hennessy, E., \& Doyle, O. (2019). 'Be good, know the rules': Children's perspectives on starting school and self-regulation. Childhood, 26(4), 509-524. https://doi.org/10.1177/0907568219840397

Britto, P. R. (2012). School readiness: A conceptual framework. United Nations Children's Fund: New York. https://www.unicef.org/earlychildhood/files/Child2Child_ConceptualFramework_FINAL(1). pdf

Bronfenbrenner, U. (1979). The ecology of human development: Experiments by design and nature. Cambridge, MA: Harvard University Press

Careless, D., \& Lam, R. (2014). The examined life: Perspectives of lower primary school students in Hong Kong. Education 3-13, 42(3), 313-329. http://dx.doi.org/10.1080/03004279.2012.689988

Commodari, E. (2013). Preschool teacher attachment, school readiness and risk of learning difficulties. Early Childhood Research Quarterly, 28(1), 123-133. https://doi.org/10.1016/j.ecresq.2012.03.004

*Cook, K. D., Dearing, E., \& Zachrisson, H. D. (2017). Information sharing between teachers and early education programs during school entry in Norway: associations with children's school adjustment and success in the first year. International Journal of Child Care and Education Policy, 11(1), 14. https://doi.org/10.1186/s40723-017-0039-5

*Correia, K., \& Marques-Pinto, A. (2016). Adaptation in the transition to school: perspectives of parents, preschool and primary school teachers. Educational Research, 58(3), 247-264. http://dx.doi.org/10.1080/00131881.2016.1200255

Dockett, S., \& Perry, B. (2013). Trends and tensions: Australian and international research about starting school. International Journal of Early Years Education, 21(2-3), 163-177. https://doi.org/10.1080/09669760.2013.832943 
Dockett, S. \& Perry, B. (2002). Who's ready for what? Young children starting school. Contemporary Issues in Early Childhood, 3(1), 67-89. https://doi.org/10.2304/ciec.2002.3.1.9

Education Bureau. (2016). Hong Kong: The facts sheets. Hong Kong: Education Bureau. Retrieved from http://www.gov. hk/en/about/abouthk/factsheets/docs/education.pdf

*Eskela-Haapanen, S., Lerkkanen, M. K., Rasku-Puttonen, H., \& Poikkeus, A. M. (2017). Children's beliefs concerning school transition. Early Child Development and Care, 187(9), 1446-1459. https://doi.org/10.1080/03004430.2016.1177041

Fabian, H. (2007). Informing Transitions. In: Dunlop, A. and Fabian, H. (eds.): Informing transitions in the early years (pp. 3-17). London: Open University Press McGraw Hill

*Griebel, W., Wildgruber, A., Schuster, A., \& Radan, J. (2017). Transition to being parents of a school-child: Parental perspective on coping of parents and child nine months after school start. In Dockett S., Griebel W., Perry B. (eds) Families and Transition to School. International Perspectives on Early Childhood Education and Development (pp. 21-36). Springer, Cham. https://doi.org/10.1007/978-3-319-58329-7_2

Hair, E., Halle, T. \& Humen, E. T. (2006). Children's school readiness in the ECLS- K: Predictions to academic. Health, and social outcomes in the first grade. Early Childhood Research Quarterly, 21(4), 431-454. https://doi.org/10.1016/j.ecresq.2006.09.005

*Hopps-Wallis, K., \& Perry, B. (2017). 'You can't Write that': The Challenges of Written Communication between Preschools and Schools. Australasian Journal of Early Childhood, 42(3), 22-30. https://doi.org/10.23965/AJEC.42.3.03

Jeynes, W. H. (2015). A meta-analysis: The relationship between father involvement and student academic achievement. Urban Education, 50(4), 387-423. https://doi.org/10.1177/0042085914525789

Heckman, J. J. (2011). The Economics of Inequality: The Value of Early Childhood Education. American $\quad$ Educator, 31-35. https://doi.org/10.1080/09669760.2018.1490849

Kagan, S. L., Moore, E., \& Bredekamp, S. (1995). Reconsidering children's early learning and development: Toward shared beliefs and vocabulary. Report of the National Education Goals Panel. Washington, DC.: U.S. Government Printing Office.

*Kaplun, C. (2019). Children's drawings speak a thousand words in their transition to school. Australasian Journal of Early Childhood, 44(4), 392-407. https://doi.org/10.1177/1836939119870887

*Kaplun, C., Dockett, S., \& Perry, B. (2017). The starting school study: Mothers' perspectives of transition to school. Australasian Journal of Early Childhood, 42(4), 56-66. https://doi.org/10.23965/AJEC.42.4.07 
Margetts, K. (2004). Identifying and supporting behaviours associated with co-operation, assertion and self-control in young children starting school. European Early Childhood Education Research Journal, 12(2), 75-85. https://doi.org/10.1080/13502930485209441

*Miller, K. (2016). Learning about children's school preparation through photographs: The use of photo elicitation interviews with low-income families. Journal of early childhood research, 14(3), 261-279. https://doi.org/10.1177/1476718X14555703

*Niklas, F., Cohrssen, C., Vidmar, M., Segerer, R., Schmiedeler, S., Galpin, R., ... \& Tayler, C. (2018). Early childhood professionals' perceptions of children's school readiness characteristics in six countries. International Journal of Educational Research, 90, 144-159. https://doi.org/10.1016/j.ijer.2018.06.001

*Nolan, A., Kilderry, A., \& Chu, C. (2019). Cross-sectoral professional relationships and transition to school: an Australian study. Early Years, 1-15. https://doi.org/10.1080/09575146.2019.1617250

Organisation for Economic Co-operation and Development. OECD (2014). Education at a glance 2014: OECD indicators. Paris: OECD Publishing. https://doi.org/10.1787/eag-2014-en

*Pass, L., Mastroyannopoulou, K., Coker, S., Murray, L., \& Dodd, H. (2017). Verbal information transfer in real-life: when mothers worry about their child starting school. Journal of Child and Family Studies, 26(8), 2324-2334. https://doi.org/10.1007/s10826-017-0735-3

Pianta, R. C., \& Hamre, B. K. (2009). Conceptualization, measurement, and improvement of classroom processes: Standardized observation can leverage capacity. Educational researcher, 38(2), 109-119. https://doi.org/10.3102/0013189X09332374

Puccioni, J. (2018). Understanding How Kindergarten Teachers' Beliefs Shape Their Transition Practices. School Community Journal, 28(1), 249-272.

*Rogers, S. (2018). 'She thinks her toys don't understand Romanian': family engagement with children's learning during the transition to school. European Early Childhood Education Research Journal, 26(2), 177-186. https://doi.org/10.1080/1350293X.2018.1441986

*Stein, K., Veisson, M., Õun, T., \& Tammemäe, T. (2019). Estonian preschool teachers' views on supporting children's school readiness. Education 3-13, 47(8), 920-932. https://doi.org/10.1080/03004279.2018.1539113

*Takriti, R. A. (2020). Children starting school in the UAE: a comparison of teacher and parent expectations. Education 3-13, 48(6), 642-650. https://doi.org/10.1080/03004279.2019.1638956

*Tao, S. S., Lau, E. Y. H., \& Yiu, H. M. (2019). Parental Involvement After the Transition to School: Are Parents' Expectations Matched by Experience?. Journal of Research in Childhood Education, 33(4), 637-653. https://doi.org/10.1080/02568543.2019.1653409 


\section{Ml Macrothink}

Journal of Studies in Education

ISSN 2162-6952

2021, Vol. 11, No. 3

UNESCO, I. (2010). World data on education. Principles and General Objectives of Education. http://www.ibe.unesco.org/sites/default/files/United_Arab_Emirates.pdf

Wesley, P. W. \& Buysse, V. (2003). Making meaning of school readiness in schools and communities. Early Childhood Research Quarterly. 18(3), 351-375. https://doi.org/10.1016/S0885-2006(03)00044-9

Wong, M. (2016a). Chinese children's perceptions of aggression among peers at school. Early years, 37(2), 143-157. https://doi.org/10.1080/09575146.2016.1178711

Wong, M. (2016b). Perceptions of school life among a sample of Chinesie children in Hong Kong. Early Child Development and Care, 188(6), 800-818. https://doi.org/10.1080/03004430.2016.1238361

Appendix 1. Characterization of the studies included in the analysis - in alphabetical order

\begin{tabular}{|c|c|c|c|c|c|}
\hline Study & $\begin{array}{l}\text { Place of data } \\
\text { collection }\end{array}$ & Time of data collection & What it targets & Samples & Methods \\
\hline Babić, 2017 & Croatia, Osijek & $\begin{array}{l}\text { a few months after } \\
\text { starting school }\end{array}$ & $\begin{array}{l}\text { learning about ideas } \\
\text { related to starting school }\end{array}$ & 6 years old child $\mathrm{N}=20$ & $\begin{array}{l}\text { semi-structured } \\
\text { interview }\end{array}$ \\
\hline $\begin{array}{l}\text { Besi \& } \\
\text { Sakellariou, } \\
2019\end{array}$ & Greece & n.d. & $\begin{array}{l}\text { cooperation, contact } \\
\text { between stakeholders }\end{array}$ & $\begin{array}{l}\text { kindergarten teacher } \mathrm{N}=748 \text {; } \\
\text { primary school techer } \mathrm{N}=643 \text {; }\end{array}$ & questionnaire \\
\hline $\begin{array}{l}\text { Booth et al. } \\
2019\end{array}$ & Ireland, Dublin & $\begin{array}{l}7 \text { months after starting } \\
\text { school }\end{array}$ & $\begin{array}{l}\text { learning about ideas } \\
\text { related to starting school }\end{array}$ & 5 years old child $\mathrm{N}=57$ & $\begin{array}{l}\text { structured and } \\
\text { semi-structured } \\
\text { interview }\end{array}$ \\
\hline $\begin{array}{l}\text { Cook et al., } \\
2017\end{array}$ & Norway & $\begin{array}{l}\text { from } 6 \text { months to the } \\
\text { end of first grade in } \\
\text { elementary school }\end{array}$ & $\begin{array}{l}\text { cooperation, contact } \\
\text { between stakeholders }\end{array}$ & $\begin{array}{l}\text { parents, kindergarten teachers } \\
\text { and primary school teachers of } \\
932 \text { children }\end{array}$ & $\begin{array}{l}\text { semi-structured } \\
\text { interview; } \\
\text { questionnaires }\end{array}$ \\
\hline $\begin{array}{l}\text { Correia \& } \\
\text { Marques- } \\
\text { Pinto, 2016 }\end{array}$ & Portugal, Lisbon & $\begin{array}{l}2-3 \text { months before and } \\
\text { after starting school }\end{array}$ & integration into school & $\begin{array}{l}\text { kindergarten teacher } \mathrm{N}=18 ; \\
\text { primary school teacher; } \mathrm{N}=13 ; \\
\text { parent whose child is a } \\
\text { preschooler } \mathrm{N}=14 ; \text { parent whose } \\
\text { child is a first grader in } \\
\text { elementary school } \mathrm{N}=20\end{array}$ & $\begin{array}{l}\text { focus group } \\
\text { interview }\end{array}$ \\
\hline $\begin{array}{l}\text { Eskela- } \\
\text { Haapanen et } \\
\text { al., } 2016\end{array}$ & Finland & end of kindergarten & $\begin{array}{l}\text { learning about ideas } \\
\text { related to starting school }\end{array}$ & $\begin{array}{l}\text { parent whose child is } 6 \text { yers old } \\
\mathrm{N}=1386\end{array}$ & $\begin{array}{l}\text { structured } \\
\text { interview }\end{array}$ \\
\hline $\begin{array}{l}\text { Griebel et al., } \\
2017\end{array}$ & Germany & $\begin{array}{l}3 \text { months before } \\
\text { starting school; } 9 \\
\text { months after starting } \\
\text { school }\end{array}$ & integration into school & parent $\mathrm{N}=108$ & $\begin{array}{l}\text { structured } \\
\text { interview }\end{array}$ \\
\hline $\begin{array}{l}\text { Hopps-Wallis } \\
\text { \& Perry, } 2017\end{array}$ & $\begin{array}{l}\text { Australia, } \\
\text { Victoria }\end{array}$ & end of kindergarten & $\begin{array}{l}\text { cooperation, contact } \\
\text { between stakeholders }\end{array}$ & $\begin{array}{l}\text { kindergarten teacher } \mathrm{N}=14 \text {; } \\
\text { primary school teacher } \mathrm{N}=16\end{array}$ & $\begin{array}{l}\text { semi-structured } \\
\text { interview; focus } \\
\text { group interview }\end{array}$ \\
\hline Kaplun et al., & Australia, & end of kindergarten; 3 & exploring the skills & mother whose child is 6 yers old & semi-structured \\
\hline
\end{tabular}




\begin{tabular}{|c|c|c|c|c|c|}
\hline 2017 & Sydney & $\begin{array}{l}\text { months after strating } \\
\text { school }\end{array}$ & $\begin{array}{l}\text { needed to start school; } \\
\text { exploring parental } \\
\text { involvement; } \\
\text { preparation for school }\end{array}$ & $\mathrm{N}=57$ & interview \\
\hline Kaplun, 2019 & $\begin{array}{l}\text { Australia, } \\
\text { Sydney }\end{array}$ & $\begin{array}{l}\text { end of kindergarten; } 3 \\
\text { months after strating } \\
\text { school }\end{array}$ & $\begin{array}{l}\text { learning about ideas } \\
\text { related to starting school }\end{array}$ & 6 years old child $\mathrm{N}=57$ & $\begin{array}{l}\text { draw-write-tell } \\
\text { technique }\end{array}$ \\
\hline Miller, 2016 & $\begin{array}{l}\text { United States, } \\
\text { State of Illinois }\end{array}$ & end of kindergarten & preparation for school & 8 family & photo-interview \\
\hline $\begin{array}{l}\text { Niklas et al., } \\
2018\end{array}$ & $\begin{array}{l}\text { Australia, } \\
\text { Austria, } \\
\text { Columbia, } \\
\text { Germany, } \\
\text { Nicaragua, } \\
\text { Slovenia }\end{array}$ & n.d. & $\begin{array}{l}\text { exploring the skills } \\
\text { needed to start school }\end{array}$ & $\begin{array}{l}\text { kindergarten school teacher and } \\
\text { primary school teacher } \mathrm{N}=1198\end{array}$ & questionnaire \\
\hline $\begin{array}{l}\text { Nolan et al., } \\
2019\end{array}$ & $\begin{array}{l}\text { Australia, New } \\
\text { South Wales }\end{array}$ & end of kindergarten & $\begin{array}{l}\text { cooperation, contact } \\
\text { between stakeholders }\end{array}$ & $\begin{array}{l}\text { kindergarten } \mathrm{N}=12 \text {; primar } \\
\text { school } \mathrm{N}=11\end{array}$ & $\begin{array}{l}\text { semi-strictured } \\
\text { interview; field } \\
\text { notes }\end{array}$ \\
\hline $\begin{array}{l}\text { Pass et al., } \\
2017\end{array}$ & United Kingdom & end of kindergarten & $\begin{array}{l}\text { learning about ideas } \\
\text { related to starting school }\end{array}$ & $\begin{array}{l}\text { mothers whose child is } 4 \text { years } \\
\text { old } N=65\end{array}$ & $\begin{array}{l}\text { questionnaires; } \\
\text { doll-play task }\end{array}$ \\
\hline $\begin{array}{l}\text { Puccioni, } \\
2018\end{array}$ & $\begin{array}{l}\text { United States, } \\
\text { Oakvale }\end{array}$ & end of kindergarten & $\begin{array}{l}\text { exploring the skills } \\
\text { needed to start school; } \\
\text { exploring parental } \\
\text { involvement }\end{array}$ & kindergarten school teacher $\mathrm{N}=3$ & $\begin{array}{l}\text { structured and } \\
\text { semi-structured } \\
\text { interview }\end{array}$ \\
\hline Rogers, 2018 & $\begin{array}{l}\text { Australia, } \\
\text { Adelaide }\end{array}$ & $\begin{array}{l}\text { a few months before } \\
\text { starting school; a few } \\
\text { months after starting } \\
\text { school }\end{array}$ & $\begin{array}{l}\text { exploring parental } \\
\text { involvement }\end{array}$ & $\begin{array}{l}\text { mother } \mathrm{N}=21 \text {; primary school } \\
\text { teacher } \mathrm{N}=13\end{array}$ & $\begin{array}{l}\text { semi-structured } \\
\text { interview }\end{array}$ \\
\hline $\begin{array}{l}\text { Stein et al., } \\
2019\end{array}$ & Estonia & end of kindergarten & $\begin{array}{l}\text { exploring the skills } \\
\text { needed to start school; } \\
\text { cooperation, contact } \\
\text { between stakeholders }\end{array}$ & $\begin{array}{l}\text { kindergarten school teacher } \\
\mathrm{N}=15\end{array}$ & $\begin{array}{l}\text { semi-structured } \\
\text { interview }\end{array}$ \\
\hline
\end{tabular}

\begin{tabular}{l|l|l|l|l|l}
\hline Takriti, 2020 & $\begin{array}{l}\text { United Arab } \\
\text { Emirates, Al Ain }\end{array}$ & $\begin{array}{l}\text { 1 month before strating } \\
\text { school }\end{array}$ & $\begin{array}{l}\text { exploring the skills } \\
\text { needed to start school }\end{array}$ & $\begin{array}{l}\text { parent N=141; primary school } \\
\text { teacher N=50 }\end{array}$ & questionnaire \\
\hline $\begin{array}{l}\text { Tao et al., } \\
2019\end{array}$ & $\begin{array}{l}\text { China, Hong } \\
\text { Kong }\end{array}$ & $\begin{array}{l}\text { 3 months before } \\
\text { strating school; 3 } \\
\text { months after strating } \\
\text { school }\end{array}$ & $\begin{array}{l}\text { exploring parental } \\
\text { involvement }\end{array}$ & mother N=20 & $\begin{array}{l}\text { semi-structured } \\
\text { interview }\end{array}$ \\
\hline Wong, 2016a & $\begin{array}{l}\text { China, Hong } \\
\text { Kong }\end{array}$ & $\begin{array}{l}\text { end of kindergarten; 3 } \\
\text { months after school } \\
\text { starting; end of the first } \\
\text { grade in primary school }\end{array}$ & $\begin{array}{l}\text { learning about ideas } \\
\text { related to starting school }\end{array}$ & $\begin{array}{l}5 \text { and 6 years old child } \\
\mathrm{N}=212\end{array}$ & $\begin{array}{l}\text { draw-and-tell } \\
\text { technique }\end{array}$ \\
\hline Wong, 2016b & $\begin{array}{l}\text { China, Hong } \\
\text { Kong }\end{array}$ & $\begin{array}{l}\text { months after school } \\
\text { starting; end of the first } \\
\text { grade in primary school }\end{array}$ & $\begin{array}{l}\text { learning about ideas } \\
\text { related to starting school }\end{array}$ & $\begin{array}{l}5 \text { and 6 years old child } \\
\mathrm{N}=212\end{array}$ & $\begin{array}{l}\text { draw-and-tell } \\
\text { technique }\end{array}$ \\
\hline Comment: n.d.=no data & \multicolumn{4}{l}{}
\end{tabular}

